\title{
RESENSI BUKU PENGANTAR PERJANJIAN BARU
}

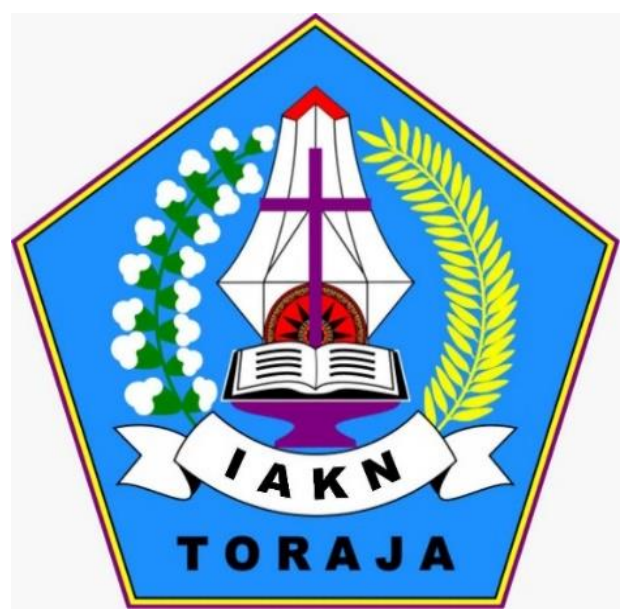

Nama: Febrianti Pamara'

NIRM: 2220207612

Kelas: A Pastoral Konseling

INSTITUT AGAMA KRISTEN NEGERI (IAKN) TORAJA 


\section{A. PENDAHULUAN}

\section{Identitas Buku:}

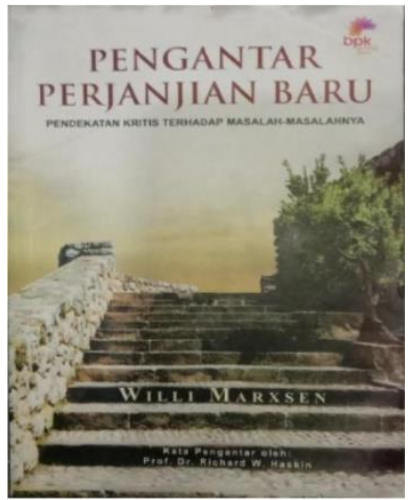

Judul Buku: Pengantar Perjanjian Baru

Penulis: Willi Marxsem

\section{Cetakan/Revisi: 1}

\section{Penerbit: BPK Gunung Mulia}

\section{Tahun Terbit: 201Kota Terbit: Surabaya}

\section{Jumlah Halaman: 351 halaman}

\section{Tujuan Penulisan}

Untuk menjelaskan berbagai isu yang telah jauh lebih kompleks dan untuk menyediakan beberapa petunjuk terhadap luasnya literatur yang telah muncul sejak revisi terakhir.

\section{Keunggulan Buku}

Buku ini jelas dan mudah diabaca tanpa mengurangi pokok-pokok pengetahuan yang perlu diketahui.

\section{B. Gagasan Utama}

Pengenalan perjanjian baru menggambarkan dedikasi Paulus sejak pendirian Gereja, kepergian Rasul untuk misi Timotius, kembalinya dia kepada Rasul, dan penulisan surat. Paulus merinci masalah yang diketahui gereja. Paulus berbeda dari pembuat mujizat kafir yang bangga berkeliling negeri, berkhotbah kepada dewa-dewa mereka, melakukan mukjizat, dan bertahan dari khotbah mereka. Paulus berbeda dari pembuat mujizat kafir yang bangga berkeliling negeri, berkhotbah kepada dewa-dewa mereka, melakukan mukjizat, dan bertahan dari khotbah mereka. Paulus membangun gereja di sana dan menerima surat dari orang Kristen 
yang melaporkan masalah gereja. Dia ingin suratnya sampai ke Korintus sebelum temannya Timotius tiba di sana. Dari surat ini Anda dapat mengetahui tentang masalah-masalah yang dihadapi oleh orang-orang Kristen mula-mula. Paulus telah menyelesaikan pekerjaan misionaris di Asia Kecil dan Yunani. Paulus dihina oleh beberapa gereja di Korintus, dan kerasulannya dianggap lemah oleh para penyiar lain yang datang ke Korintus. Paulus tampaknya telah menulis surat yang sangat besar berterima kasih kepadanya karena membatalkan kunjungannya ke Korintus dan memulihkan hubungannya dengan Gereja Korintus melalui intervensi Titus. Dia bermaksud untuk memulai pekerjaan serupa di Spanyol. Untuk tujuan ini, dia ingin mendapatkan bantuan dari orang-orang Kristen Romawi. Dalam surat ini dia menguraikan Injilnya tentang Yesus Kristus. Surat ini bukan sembarang surat. Dia lebih seperti keledai. Dalam surat Roma, Paulus secara tegas menyatakan bahwa Injil adalah kekuatan Allah yang menyelamatkan setiap orang percaya, tidak menjadi soal dia Yahudi atau bukan Yahudi

\section{Evaluasi Kritis dan Rekomendasi}

1. Tata bahasa buku Pengantar Perjanjian Baru ini menggunakan bahasa yang baku, rinci dan jelas juga terstruktur dengan jelas. Terbitnya buku ini dalam Bahasa Indonesia perlu dibaca karena jelas merupakan keuntungan bagi komunitas teologi.

2. Strukur Buku

- Pendahuluan (Kata pengantar, prakata, daftar singkatan, daftar isi)

- Isi (Pendekatan teologis terhadap pengantar perjanjian baru, surat-surat Paulus, Injil sinoptik dan kisah para rasul, surat-surat pseudo Paulus, suratsurat Am (gerejawi), tulisan-tulisan Yohanes, sastra apokaliptis)

3. Teori dari buku tidak ada

4. Saran

Sebaiknya penulis tidak membatasi bahan pengetahuan dalam buku ini sehingga memberikan pemahaman teologi yang mendalam dan buku ini lebih baik dibaca oleh para mahasiswa atau para dosen daripada orang awam. 